\title{
When reality has become a pale reflection of our images... Imagining faith in Christ in a postmodern context 1
}

D P Veldsman

\begin{abstract}
When reality has become a pale reflection of our images... Imagining faith in Christ in a postmodern context

Closely following the philosopher Richard Kearney's "The wake of imagination" (1988) and "The poetics of imagining" (1991), the historical trial of the act of imagination is explicated. The implications of this very act of imagination are explored within a postmodem context. The question of the reconstruction of a christology within such a postmodern context, characterised by epistemological undecideability and depthlessness, is addressed. Finally, tentative suggestions are made for an engaged christology (that is an ethical-poetical christology) in which the presence of Christ has to be renamed as there are still stories being told.
\end{abstract}

INTRODUCTION

"Imagining cannot be expected to mean exactly the same thing today as it did in the Middle Ages or in antiquity. For one thing, Aristotle and Aquinas never watched television"2.

Reflection on the meaning of the person and work of Christ, is called christology 3 . Followers of Jesus Christ, that is, believers committed and conforming to the "image" of Christ, are called Christians. The naming of followers of Christ as Christians, presupposes an "as if" existential-theological relationship between Christ and his followers ${ }^{4}$. Both elements constitute the Christ-experience as socio-historic dynamic of religious experience5. Being Christian relates directly to specific traditions (remembering), commitments and (life)styles (imagination), and expectations (hope). And these three (remembering, imagination and hope) are one in the moment (Augenblick) of existence ${ }^{6}$.

This philosophic-theological paper with its genealogical approach and confined to Western culture, explores tentatively this act of imagining by (a) telling in broad outlines the story of imagination imaginatively in its changing course of history and (b) exploring the implications of this very changing act of imagination within a postmodern context (also called - within Western culture - a Civilization of 
the Image). Four questions will lead our way: (1) Why tell the story of imagination; (2) Where do we begin with the story and what is this story; (3) What is the implications of this story within a postmodern context and (4) ultimately for christology?

Why must the story - of all things! - of imagination be told? Simply - in the first place - because imagination ${ }^{7}$ is not only at the heart of ways of being in the world, it is also an instrument of truth. Thus the story of imagination, which is as old as creation itself, tells a story of mankind's search for (ultimate) meaning. To tell is therefore not "murder to dissect", but to keep the "difficulty to live (meaningful read imaginatively) alive" (Caputo). Secondly, I am convinced that to take Christ's incarnation seriously, that precisely this "to take seriously" His life, my life and the life of others as well as that of the world, begins with "imagining". At the very same time, it is this very (imaginative) mystery which sustains us. Furthermore, I believe that all the different modes/ways of empowerment within a society, are executed as concrete acts of imagining, that is, dreams that have become visions, and visions that have become concrete acts of (critically) changing "ways of being" in this world. Fourthly, to tell the story of imagination, is to lay the table of possibilities of living for the living, to critically explore the resources of "ways for being" from the past in the light of the future for the presence. And this presence is - lastly, and above all characterised by images. The culture of the Book - so it seems - is being replaced by the culture of the Image in a world of mass communication and consumerist media. Kearney ${ }^{9}$ informatively states:

"The contemporary eye is no longer innocent. What we see is almost invariable informed by prefabricated images. There is, of course, a fundamental difference between the image of today and former times: now the image precedes the reality it is supposed to represent. Or to put it another way, reality has become a pale reflection of the image".

This has given rise to the impasse where the very rapport between imagination and reality seems not only inverted, but subverted altogether. Now we cannot be too sure which is which. Has the power of imagination, which - as will be shown in this paper - has always been a mixed blessing (liberation and curse) for (wo)mankind ${ }^{10}$, now not only lost its innocence, but is it not also dancing its final dance on its own grave ${ }^{11}$ ? These reasons suffice for telling the story of imagination. A story which has to follow the historical trail of a plurality of terms: yetser, phantasie, eikasia, imaginatio, Einbildungskraft, fantasy, imagination ${ }^{12}$. To tell - in terms of these terms 
- is to historically map where we come from. But to tell is to simultaneously plot a future and to discern a way forward in a world of reproduction, in a world confused by the mass media with the relationship of reality to image, and which paradoxically threatens the very notion of a creative human imagination. How this has come to pass and its implications, must be made clear from the story of imagination itself.

Where do we begin? We must begin at the beginning: At the very foundational myths of Western culture ${ }^{13}$. Especially two are important in this context: Adam and Eva (Hebraic imagination) and Prometheus (Hellenic imagination). And here we shall begin. These two foundational myths characterise the "first" period (or better: paradigm) in the (hi)story of imagination. This period will be called PRE-MODERN (up to the 15th century), in distinction to the MODERN (16th to 20th century) and POSTMODERN (20th century) periods respectively.

\subsection{A the pre-modern period (up to the 15 th century)}

\subsubsection{The freedom to choose and imagination: an ethical tale}

The birth of the human power of imagining (in Hebrew yetser, from the same root as the term for "creation/create") coincides with Adam's transgression of God's law. Imagination, that is, man's creative impulse to imitate God's own creation has fallen with the paradisic transgression to an imagination which imagined a world of Adam's own making. Imagination is henceforth identified with the knowledge of opposites, good and evil, past and future. As the freedom of choice was actualised, so time was born. The result? An ethical (good and evil) and historical (past and future) consciousness. Two points are here of importance: The concept of yetser resides in its emphasis on man's free choice between good and evil. Evil is thus not a cosmological property of being, but an anthropological act. Man can thus choose or refuse evil as an option of its human imagination as it constructs its historical destiny. In this sense imagination was a mixed blessing (liberation and curse).

Proceeding from the story of Adam and within the broader Hebraic world of interpretation of the significance of imagination, four fundamental properties can be identified in the Hebraic imagination, namely (a) mimetic, that is, a human imitation of the divine act of creation; (b) ethical, that is, a choice between good and evil; (c) historical, that is, a projection of future possibilities of existence and (d) anthropological, that is, as activity proper to man which opens up a freedom of becoming beyond the necessity of cosmic being.

2.1.2 Fore-sight and imagination: An epistemological tale

Although the first philosophical categories of the Hellenic imagination are to be 
found in the writings of Plato and Aristotle, a glance at a Greek equivalent of the story of Adam ${ }^{14}$, namely the myth of Prometheus ${ }^{15}$, is more than just interesting. More than just interesting as we see a shift from the ethical (Adamic myth) to the epistemological dimension (Prometheus) of imagination.

The Promethean myth describes how man first acquired the power to shape his world, to create arts and images capable of transforming nature into culture. The name Prometheus (meaning foresight) designates the power to anticipate the future by projecting a horizon of imaginary possibilities. As in the story of Adam, so too was imagination in the story of Prometheus, a liberation and a curse. In both stories the acquisition of imagination is portrayed as an offense against the gods. Evil, however, is portrayed not as an anthropological act as in the Adamic myth, but is attributed to a pre-existing cosmic destiny of which man and the gods themselves are victims.

\subsubsection{Plato: The condemnation of imagination}

The notion of imagination received its first properly philosophical formulation with Plato - and it was very (not entirely) negative! A few remarks suffice. Plato's epistemological opposition between the knowing faculty of reason and the mimetic functions of imagination (eikasia and phantasia ${ }^{16}$ ) must be understood in the larger context of his metaphysical distinction between being and becoming. Aristotle acknowledges that the human ability to "erect images of the gods" means that mortals can set themselves up as rivals to the divine demiurge. Plato cautions against the making of images as a mere imitation of truth whereby artist and sophist alike fabricate fake copies of reality. Imagination is condemned ${ }^{17}$ as a pernicious strategy of simulation: one which tempts mortals to take themselves for omniscient gods, whereas in fact they are merely playing with reflections in a mirror. For Plato, the human imagination is only deemed legitimate to the extent that it acknowledges three conditions: (1) That it is an imitation rather than an original; (2) That it is ultimately subordinate to reason and (3) that it serves the interests of the divine Good as absolute origin of truth. If not, it is to be condemned without hesitation and without reprieve.

\subsubsection{Aristotle and imagination: From a negative "idealism" to a more positive "realism"}

Aristotle - and this is an important difference from Plato 18 - placed the emphasis in his theory of imagining on the role of the image as a mental intermediary between sensation and reason rather than as an idolatrous imitation of a divine demiurge. Imagination was not in itself the origin of meaning, but served higher truths, that is, 
truths which existed beyond our images of them. Images thus still served as a copy rather than an original, but was validated as a generally reliable copy rather than an illusory copy of a copy. The function of the image was to represent reality to reason in as faithful a manner as possible. The image served as a bridge between the inner and the outer. It was both a window on the world and a mirror in the mind. Thus Aristotle departed from Plato's "idealist" epistemology to a "realism" in which imagination played a positive role in the human process of knowledge ${ }^{19}$. This implied that the terrain of investigation shifted from a metaphysical to a psychological level. In short: imagination was psychologized.

This positive role, however, did not mean that Aristotle permitted imagination any freedom in its own right. Although he admitted that there could be no thinking without the intermediary role of images, he still held to the view that imagination was for the most part false 20 .

Imagination thus remained for both these founding fathers of Greek philosophy a reproductive rather than a productive activity, a servant rather than a master of meaning, imitation rather than origin.

2.1.5 The tales of two cities (Jerusalem and Athens) became the tale of a city: Medieval imagination as a synthesis of Biblical and Greek concepts

Medieval thought (fifth to fifteenth century) was largely (although not exclusively) a synthesis of biblical theology and Greek ontology, of the Judeo-Christian notion of a Divine Creator and the Platonic-Aristotelian metaphysics of being 21. This synthesis can be called "onto-theological", that is an identification of God and Being. Of this synthesis, St Augustine (fourth century) and St Thomas Aquinas (thirteenth century) were the most influential authors.

St Augustine (Augustine) was an influential forerunner of the medieval theories of imagination. He was the first Latin author to use the term imaginatio in a consistent philosophical manner, combining the biblical distrust of images with the Greek and neo-Platonic view of phantasia as a hindrance to spiritual contemplation 22. For Augustine, imagination was "mimetic" representation. The image, observing the strict limits of reproduction, referred to some original reality beyond itself and could never lay claim to the status of originality which was the prerogative of the divine. In short: imaginatio was the humble servant of a higher intellect!

With his systematic synthesis ("onto-theological") of the God of revelation and the metaphysical understanding of the categories of Being, Augustine paved the way for the famous medieval model of faith seeking understanding. But precisely this model - as an onto-theological synthesis (or alliance) - carried a double negative 
charge toward imagination (transgression, counterfeit). Subsequently the suspicion toward imagination was deepened. Precisely how?

It (that is, the synthesis) combined and consolidated the biblical condemnation of imagination as transgression of the divine order (- as ethical disorder -) of creation and the metaphysical critique of imagination as a counterfeit of the original truth of Being (as epistemological disorder).

St Thomas Aquinas in his scholastic realism, represents the crowning achievement of this synthesis of theology and ontology23. He combined the Platonic notion of a pure noetic realm devoid of images with the Aristotelian doctrine that forms cannot be mentally represented without images. He consolidated the medieval conception of imagination - for which he used the terms imaginatio and phantasia - as a mediational faculty between mind and body. Aquinas added a special "verbal touch" to imagination, depicting it as a "storehouse of forms received through the senses" 24 .

The medieval understanding of imagination - true to its dual ontotheological nature - conforms to the fundamentally "mimetic" model of both its Greek and biblical origins. The image is treated as an imitation and is never considered as an original in its own right. It had the function of mediation and this mediation could be positive (that is, relating the inner world of the mind to the outer world of the body and vice versa) or negative (that is, in the measure that it frequently deviated from the supervision of the higher intellect and confused the rational with the irrational, the spiritual with the sensible, being with non-being). What then was the official and final verdict on imagination of medieval philosophy? Put bluntly: Guilty as hell25.

\subsection{The modern period (16th to 20th century)}

\section{$2.2 \quad$ Imagination as lamp}

What is the most distinguishing trademark of the shift from the pre-modern to the modern period? Unmistakably the affirmation of the creative power of man. The mimetic understanding of imagination is replaced by the productive, the intermediary function of imagination by the conviction that imagination was the immediate source of its own truth ${ }^{26}$. What did this shift imply for the significance of imagination? A lot! Perhaps this is saying too little? Better then: everything! Imagination was now deemed capable of inventing a world out of its own resources, a world answerable to no power higher than itself. Imagination ceased to function as a mirror reflecting some external reality. It now became a lamp, a lamp which projected its own internally generated light onto things. What did this shift entail for the understanding of the origin of meaning? Meaning was no longer primarily 
considered as a transcendental property of divine being. It was now hailed as a transcendental product of the human mind. Imagination - released from its "heavenly imprisonment", freed from the copyright of heaven on the origin of meaning - was seen as the divine spark in man. The anthropological truth thus replaced the onto-theological truth and man could now declare his autonomy from all given being. But how was this achieved?

Three interconnected convictions made it possible:

* Imagining was an original "production" of human consciousness

- The image was a dynamic creative act

* The image was an inner transcendental unity.

This far-reaching shift - called by Kearney the "Copernican Revolution" - first became effective with Kant in the 18th century ${ }^{27}$. Its forerunning roots, however, were to be found in Renaissance mysticism, Cartesianism and Empiricism ${ }^{28}$. First a few remarks concerning these roots whose main contribution were the removal of the stigma of the Promethean theft and the establishing of the human imagination as the source of universal light and power. The charges against imagination was dropped. The accused became the jury as well as the judge!

Renaissance mysticism: Paracelsus and Bruno were two of the most interesting proponents of such mystical tendencies. The former set the tone for most alchemical theories of imagination when he described it as the "sun" whose light is not tangible but which can set flame to a house. Imagination was the privileged expression of man's desire to be the sun ${ }^{29}$. Imagination was the divine flame within man. Bruno - an Italian thinker of the sixteenth century - on his part, hailed the human imagination as the creative source of the "forms" of thought. The material world was to be transformed by man's own imagination in accordance with a hidden cosmic design. Furthermore, imagination was the privileged vehicle of the Holy Spirit. The very important emphasis that has to be noticed, is that Bruno held imagination to be properly human rather than divine. The reaction to Bruno's standpoint - in my opinion - was rather harsh: He was condemned as a heretic and burnt at the stake! So much for an imaginative response from his adversaries!

Cartesianism: Descartes, with his famous formulation of cogito engo sum ("I think therefore I am"), did more for human subjectivity than he did for imagination. It was Kant who "did it for imagination"! Although Descartes located the source of meaning in human subjectivity rather than in the objective world of reality, he did not drop the traditional bias against imagination ${ }^{30}$. He continued to subscribe to the received view of imagination as a mere intermediary between mind and body ${ }^{31}$. However, profiling subjectivity the way he did prepared the Kantian table for the feast of imagination which was to come. 
Empiricism: setting out as a positivist rationalist, Hume ended up a radical skeptic. Hume had proposed to show how knowledge could dispense with all appeals to transcendent beings or deities, how it could establish its own foundation in the immanence of human reason. For him, all human knowledge was derived from the association of images-ideas. The mimetic image no longer referred to some transcendent origin of truth, but became an end in itself. The only truth we could know, was that of our image-representations (and that meant no truth at all!). The connection here with Kant, is clear.

Kant: Kant rescued imagination ("Einbildungskraft") from its servile role as an intermediatory faculty between our sensible and intelligible experience, declaring it to be the primary and indispensable precondition of all knowledge 32 . Imagination became the sine qua non of all genuine knowledge. Nothing could be known about the world unless it was first preformed and transformed by the synthetic power of imagination. Reproductive imagination became the productive imagination! Being was not first and foremost some transcendent deity which produced human meaning, but rather a product of man's own transcendental imagination. But what does transcendental imagination mean?

Imagination was the hidden condition of all knowledge. It was an "art concealed in the depths of the human soul". It was that which grounded the objectivity of the object in the subjectivity of the subject. "Transcendental" was thus concerned with the presuppositions of experience, that is, that which made experience possible in the first place 33 . Imagination thus ceased to be a copy, or a copy of a copy, and assumed the role of ultimate origin. The mirror turns lamp (Yeats).

Owing to Kant and his admission, the entire hierarchy of traditional epistemology was turned on its head. Kearney states in this regard: "After Kant, imagination could not be denied a central place in the modern theories of knowledge (epistemology), art (aesthetics) or existence (ontology)"34.

After Kant and the "central place" of imagination, then what? In the Kantian wake followed German idealism (Fichte, Schelling) ${ }^{35}$ and Romanticism (Coleridge, Baudelaire and others). The productive imagination in the "hands" (read heads!) of the German idealists and Romantics left no stone of subjectivity unturned. The sharp Kantian demarcation between that which could and could not be known, collapsed. The human imagination was even identified with the Divine Mind, elevating imagination to the rank of omnipotence. Having conquered the universe, there appeared to be nothing that imagination could not do. Could not do? Imagination was soon to find itself in dire straits and disillusioned! The "central place" of imagination was invaded by the "market place". What did this mean? Imagination simply could not deliver on its promises. Social conflict, political and economical turmoil thrashed the hope of the "emancipated and empowered" imagi- 
nation to transform reality. Yes, imagination could continue to form images. No, it could no longer hope to transform reality ${ }^{36}$. The collapse of imagination's dream is the point where romantic idealism ended and existentialism began! Existentialism "clip(ped) the wings of the transcendental imagination" 37 and brought it back to earth.

\subsubsection{Existentialism: robbing the shine of the lamp of romantic idealism}

Although existentialism agreed with romantic idealism with regard to the productive power of imagination which preceded both sensation and intelligence, it reintroduced the baggage of cumbersome distress which idealism sought to leave outside. In affirming the condition of aesthetic existence, romantic idealism at the very same time concealed the condition of social existence. And its condition was now laid bare by the operative terms of the existentialist philosophy: anguish, dread, absurdity, nothingness, nausea, bad faith ${ }^{38}$. Although freedom, happiness and beauty remained the goal of the "modern bourgeoisie", the realization thereof continued to be denied in the social world. These very goals became a "compensatory illusion". It was for the first generation ${ }^{39}$ of existentialists thinkers (Kierkegaard, Nietzsche) to grapple with this illusion. Both thinkers however, never developed a systematic philosophy of imagination per se. Both sponsored the view that man's imagination is confronted with the absurdity of his existential situation. This absurdity however is very differently addressed. Whereas Kierkegaard's ${ }^{40}$ confrontation with the absurdity of man's existential situation embraced the paradox of the leap of faith, warning that the gravest error of modern spirit was to confound human imagination with what he called divine "invention", Nietzsche in turn "celebrated" the foundationlessness, the free-floating nothingness "Let nothingness be"41 of creative imagination 42 . For Nietzsche this was the very challenge of modern man to exist without alibi or reprieve, without any recourse to higher values. Imagination was the demand to live dangerously.

The second generation of existentialist thinkers (Camus, Heidegger, Sartre) brought the modern philosophy of imagination to its ultimate humanist conclusion. And this conclusion - said mildly - spelt "unhappy times" 43 . By the time of the second generation of existentialist thinkers, the "affirmative" dreams of the enlightenment and idealist thinkers had degenerated into the nightmare of a global warfare which shook European civilization to its very foundation.

Camus proclaimed the necessity of facing up to the meaninglessness of existence and to meet the problem of suicide face to face. To combat this meaninglessness meant to reassert the creative power of imagination, while candidly admitting the "absurd" nature of this creation 44 . Between man's search for meaning and the meaninglessness of the universe was an incorrigible discrepancy. 
Heidegger's theory of imagination is, by his own confession, an existential reinterpretation of the Kantian concept of transcendental imagination ${ }^{45}$. But this conversion from transcendental to existential required a change of terminology: Dasein for imagination! The concept Dasein embodied the temporalizing activity of imagination while avoiding the idealist and romantic characteristics attached to this term by Kant and his successors ${ }^{46}$. This temporal activity of human existence is defined by Heidegger as a finite being-towards-death which projects itself out of nothing towards nothing. Heidegger wanted to move beyond the anthropological basis of modern idealism to a philosophy which reveals that human being, qua Dasein, is in fact grounded on the non-ground of nothingness, a non-ground which gapes within Being. Bringing the humanist philosophy of imagination to the point of its own self-overcoming as Dasein, the end of imagination is anticipated. And by implication, the end of man.

Sartre's phenomenology of imagination ${ }^{47}$ was the last attempt of modern philosophy to restore an anthropological basis to the creative imagination. His option to retain the concept of imagination, was an option for humanism. In this he differed from Heidegger, maintaining that the end of man is still man. Following the phenomenologist Husserl's account of the image as an act of consciousness, Sartre was not interested in imagination as an empirical state of mind, but as a phenomenon of human significance. Thus he wanted to describe images as they first appeared (phainesthai) to us in the form of intentional projections of consciousness. The image, as a spontaneous act of consciousness, was independent of both the percept and the concept. Thus it was characterised as a quasi-reality (also depicted as quasi-observation) while the image itself, was for Sartre a nothingness ${ }^{48}$. In the words of Kearney: "Imagination is a sui generis mode of intentionality which frequently seeks to deny what it specifically is (unreal) in favour of what it would like to be (real)" 49 .

Imagining was thus for Sartre an act of negation and this negation 50 , the very basis of consciousness. And in this very act of negation (that is, distancing one from the world), imagination revealed itself as freedom (that is, relating to the world) ${ }^{51}$. What however, did this act of negation imply for the significance of meaning? This very act of negation lead to the unavoidable conclusion that meaning is nothing other than the nothingness projected by the imagining subject himself.

The existentialist thinkers did not only rob the shine of the lamp of creative imagination. The lamp itself now grew dim, being smothered by its own shadow of pure negativity. It was now left to the postmodern thinkers, living in a "Civilization of the Image" (Roland Barthes), to come to terms with the smothering lamp. 


\subsubsection{From smothering lamp to looking glass}

Within a postmodern context ${ }^{52}$, characterised as the Civilization of the Image, the very opposite of the expectation of a privileged place for imagination, materialised. We find the demise of the creative imagination. Structuralists, post-structuralists and deconstructuralists dismantled the very notion of imagination and imagination, subverted through a new textual revolution, appears to be dissolving into an anonymous play of language ${ }^{53}$.

What was and is the "historic force" behind the dismissal of the creative imagination? Kearney sees it as follow: "(W)e seem to have entered an age where reality is inseparable from the image, where the original has been replaced by its imitation, where our understanding of the world is preconditioned by the electronically reproducible media of television, cinema, video and radio - media in which every 'live' event or performance is capable of being mechanically recorded and retransmitted ad infinitum ${ }^{54 " .}$

Thus, the representational image has began to overshadow reality itself. History has become a pale replica of its own reproduction. Put more strongly: The imaginary has become more persuasive than the real world through the technological innovations in image reproduction. This very crisis is reflected in postmodern philosophies in which imagination is no longer understood as an original creation of meaning. And deprived of "origin", the concept of imagination itself collapsed, regardless whether the model of origination was situated outside of man (the pre-modern period) or inside of man (the modern period). The mirror, which turned lamp, now turned looking glass, that is, a "labyrinth of mirrors which extends infinitely in all directions"55. A labyrinth where the image of the self dissolves into self-parody56. In a curious way, the postmodern period has returned to the "mirror" of the pre-modern period, but it is a return which is an inversion: not an imitation of some pre-existing truth, but with an imitation of an imitation - with no original beyond itself.

Apart from this "historic" influence of the mass media, another prime factor must be named: The influence of the discovery of the unconscious and the subsequent (diverging) interpretations thereof 57 . Thinkers such as Lacan, Althusser, Foucault, Levi-Strauss and Derrida seem to celebrate the disclosure of an unconscious system of language as a key to the dismantling of the humanist imagination understood as an autonomous entity 58 . For Lacan, the imaginary must die in order for the symbolic other to live. Althusser equates the imaginary with the false consciousness of the bourgeoisie. Foucault, concentrating on the epistemological dimensions of the imagination (although he does not directly attack 
the concept of imagination), pronounced the "death/end" of man, and thus, by implication, the end of the creative imagination. Barthes in turn, treating the imaginary as mere myth, seeks to demystify the representations of the collective imaginary which transform "petit-bourgeoisie culture into a universal nature". And lastly - most probably the deconstructionist par exellence - Derrida, who urged that the "end of man" had to be thought through, that is - if applied to imaginary - the deconstructive readings of metaphysical modes of representation.

Does this mean we have to face the death of imagination? But the death of imagination implies the death of a philosophy of truth, and consequently, the end of (wo)man! Or: can we overcome the feeling of paralysis in the labyrinth of endless play, of trapped minds in the undecidable relationship between image and reality which characterises the postmodern context? And the most important of all: what implications does this have for constructing a Christology?

\subsection{Coming face to face within a postmodern context: a way forward for imagination?}

\subsubsection{Seeing the face behind the mask}

"On the far side of the self-reflecting looking glass, beyond the play of masks and mirrors, there are human beings who suffer and struggle, live and die, hope and despair"59.

There is no return ticket to yesterday. However, to not give in, to not surrender to the pessimism of the postmodern culture, but to grapple interpretatively with this very culture, starts with a task of revision. How do we pass through the dark night of undecideability and the labyrinth of depthless images by means of the task of revision?

In so far as the postmodern culture undermines every attempt to establish a decidable relationship between image and reality, that is, in so far as it admits of no epistemological limits, it must - and this is the crucial point - recognize ethical limits. Epistemological undecideability does not imply ethical undecideability. In the words of Kearney: "We reach a point in the endless spiral of undecideability where each one of us is obliged to make an ethical decision, to say: here I stand. (Or, at the level of collective responsibility, here we stand). Here and now, in the face of the postmodern logic of interminable deferment and infinite regress, of floating signifiers and vanishing signifieds, here and now I face an other who demands of me an ethical response"60.

It is precisely the ethical responsibility and the ethical response that reintroduces a dimension of depth. It is to come "face to face" (Levinas) with one another: the other as an other ${ }^{61}$. The other in need makes an ethical demand upon 
me. The question "where are you?" (ethical demand) must be asked before the question "who are you?" (epistemological question), that is, an ethical priority over the epistemological question 62 . The good comes before the question of truth and being. Does this imply uncritical action? No. It demands constant discernment ${ }^{63}$. But how does this relate to imagination and the postmodern challenge? This calls for an ethical reinterpretation of imagination, that is, challenging postmodernism by debunking the conventional models of imagination as either a sovereign master or a mimetic servant of meaning, and submitting deconstruction to ethics and to reinterpret the role of imagination as a relationship between the self and the other ${ }^{64}$. It is to imagine otherwise, that is, an imagination that is able to respond: here I am 65 . This responsive imagination - as the only credible creative imagination in our postmodern age - is one which knows that the shortest root from self to self is through the images of others (that is, the discourse of a social and cultural imaginary). Or in short: "The other will not leave imagination be"66. However, the responsive imagination can not only be ethical. It is not enough. It must also be poetical (that is, being ethical in a liberating way).

This necessary and complementary poetical dimension is described by Kearney ${ }^{67}$ as follows: "It is a creative letting go of the drive for possession, of the calculus of means and ends. It allows the rose... to exist without why (Silesius). Poetics is the carnival of possibilities where everything is permitted, nothing censored. It is the willingness to imagine oneself in the other person's skin, to see things as if one were, momentarily at least, to experience how the other half lives".

In short: the poetical imagination nourishes the conviction that things can be changed 68 . But the ethical and poetical - albeit two different ways in which imagination can open us to the otherness of the other - belongs together. The poetical readiness to tolerate the undecideability of play must be considered in relation to the ethical readiness to decide between different modes of response to the other. And this response to the other must take heart of the lessons learnt from history. It must be prepared to listen to the lessons of its own stories. Lesson one from the pre-modern period: imagination is always a response to the demands of an other existing beyond the self. Lesson two from the modern period: never abdicate a personal responsibility for invention, decision and action. Lesson three from the postmodern period: we are living in a Civilization of Images, a civilization which can bring each one of us into contact with each other despite the confusion between image and reality.

The task of revision is consequently hermeneutic (discriminating, integrating), historical (remembering the past to change the future), narrative (to tell and retell one's story, enabling the proliferation of the narrative identity) ${ }^{69}$. What does this then - finally - imply for a christology? 
How are we to respond within a postmodern context - characterised by epistemological undecideability and depthlessness - in our different constructions of christologies? I would like to make the following tentative suggestions.

Taking Christ's incarnation seriously, is to be committed to a lifestyle which seeks the realisation of the coming of God's kingdom. This coming of God's kingdom as God's story in our world, told and written anew in imaginary commitment and conformation (that is, being the image of God and conforming in action to the image of Christ) must bring men, women and children face to face with one another and enabling the naming and recognition of the risen Lord in our midst. In short: to face God in the other. Such a christology which seeks to bring one another face to face, will be ethical-poetical christology, that is: a christology which is a process where someone says something to someone about something. In short: christology must be structured as response and address, that is, the practical and concrete manifestation of God's kingdom in a given place and at a given time (cf Matt 25:3146). As response and address, this will be a learning experience, that is, learning to know and to speak about God and our world. Learning "to believe and to be obedient" in conformation to Jesus of whom was said in Heb 5:7-10: "In the course of his earthly life he offered up prayers and petitions, with loud cries and tears, to God who was able to deliver him from death. Because of his devotion his prayer was heard: son though he was, he learned obedience through his suffering, and, once perfected, he become the source of eternal salvation for all who obey him".

This is the learning experience of our faith which, in my opinion, is the vantage point for an ethical-poetical christology, asking in the first place: where are you? and not: who do you say I am"70? Such a christology will be:

*utopian, that is, exploring self-critically and learning "ways of being" Christians in our world, that is, the imaginative ability to disclose the possible in the actual, the other in the same, converging differences without fusing, the new in the old, and the never-yet realized enabling to guard against dogmatism;

"testimonial, that is, the power to bear witness to "exemplary" narratives legacied by our cultural memories and traditions. It is to listen and respond to one another's stories (that is, the imaginative ability to put oneself in others' shoes, to identify oneself with their actions, thoughts or feelings). It is also to recall the forgotten victims of history (that is, rememoration). It is precisely this testimonial dimension which helps the utopian dimension not to degenerate into empty fantasy. Together the 
utopian and testimonial dimensions are the formative powers for historical criteria for our judgments.

*emphatic, that is, to remain open to what is given from beyond (to be receptive), to respect the otherness of the other person, to treat the other as and end rather than a means, to expose oneself in welcoming the stranger, to empathize. It is - in short - a receptivity that becomes compassion.

\section{CONCLUSION}

Finally: with the winds of change storming in our country, our responsible task is learning and critically discerning a responsive christology, an engaged christology in which we shall have to rename the presence of Christ as there are still stories being told. A presence, which has the character of which John 3:7-8 has written: "You ought not to be astonished when I say, 'You must all be born again. The wind blows where it wills; you hear the sound of it, but you do not know where it comes from or where it is going. So it is with everyone who is born from the Spirit".

In this way a christology can address, not only the epistemological undecideability and depthlessness of our age, but learn to come face to face with Christ's presence in our midst.

\section{NOTES:}

1 Paper delivered at the annual meeting of the Theological Society of Southern Africa at the University of Cape Town on the 18-20 August 1993. This article is dedicated in appreciation to professor $\mathbf{J}$ A Heyns, my inspiring teacher in Dogmatics and Ethics of the Dutch Reformed Faculty of Theology, University of Pretoria. In his pioneering systematic-theological reflection he has not only shown us a way, but he has given me the confidence to explore another way on my own.

2 Richard Kearney, Poetics of Imagining. From Husserl to Lyotard, London $1991,6$.

3 Although "christology" has become a rather strict technical term within scholarly circles, I am using this term in a "weak and soft" sense, that is, refering inclusively to all (un)structured reflection on all levels (personal, confessional and scientific) on the meaning of the person and work of Christ.

4 The "as if" refers to the metaphoric nature of reflection on this relationship; existential refers to commitment and lifestyles; theological refers to specific traditions of interpretation. 
5 See D P Veldsman, "Religieuse ervaring as Aspoestertjie van teologiese besinning", Hervormde Teologiese Studies 46/3 (1991), 323-44 and D P Veldsman, "Remembering as socio-historic dynamic of religious experience", Scriptura 42 (1992), 1-16.

$6 \quad$ See D P Veldsman, "Religieuse ervaring as herin-neringsvolle verbeelding", Scriptura 46 (1993), 50-65 and D P Veldsman, "A postmodern Christology with Christ but without the Son of God?", Henormde Teologiese Studies 49/3 (1993), 577-94.

7 I am not elaborating any further on the very difficult and polysemantic concept of imagination as such. This I have done elsewhere (cf Veldsman, op cit, 1992; Veldsman, op cit, 1993). A short summary for interpretation purposes is however appropriate. In order to avoid two extremes of interpretation, namely the nominalist and essentialist claim (cf Richard Kearney, The wake of imagining. Toward a postmodern culture, Minneapolis 1988, 16), four main meanings of the term could be identified: (1) To experience the absent as present (that is, the ability to evoke absent objects which exist elsewhere, without confusing these absent objects with things present here and now); (2) To represent real things in some "unreal" way (e g paintings, statues, photographs); (3) The fictional projection of non-existent things (e g literary narratives, dreams); (4) To be fascinated by illusions (that is, to confuse what is real with what is unreal).

8 Imagination is of course itself an indispensable condition of all story-telling! Furthermore, the question of imagining resembles the question of being in that both relate to something so obvious as to be overlooked and so elusive as to be unnameable. In this regard, Kearney, op cit, 1991, 5 adds: "(Imagination is) a paradoxical phenomenon, now here, now gone. Something, as the poet said, 'more distant than the stars and nearer than the eye"".

9 Kearney, op cit, 1988, 2.

10 Sexist language - for which I am also very sensitive -will be avoided as far as possible, although unfortunately not when impractical or when being ludicrous.

11 The implication? The death of imagination spells the demise of man.

12 Although we find numerous terms for "imagination", these terms have at least one basic trait in common. They all refer in their diverse ways to the human power to convert absence into presence, actuality into possibility, what-is into something-other-than-it-is. In short, they all designate our ability to transform the time and space of our environment into a specifically human mode of existence (cf Kearney, op cit, 1991, 4).

13 In telling this story, I am greatly indebted to the two excellent works of Kearney, op cit, 1988, and Kearney, op cit, 1991. See Kearney, op cit, 1988, 38,79 and Kearney, op cit, 1991, 2 for the reasons for the special merit of 
attention to these two narratives as founding narratives of the story of imagination.

14 For the interesting parallels between these two stories, see Kearney, op cit, 1988, 81-7.

15 The story runs as follow: Prometheus stole fire from the gods and bestowed it upon man. Angered by his transgression, Zeus punished Prometheus by chaining him to a rock and sending an eagle to devour his liver. With the use of this stolen fire, man was able to invent his own world. The stigma of theft was thus attached to imagination, understood broadly as the Promethean foresight which enabled man to imitate the gods (cf Kearney, op cit, 1988, $80)$.

16 These two terms used by Plato to denote the imagining function are by no means synonomous. Both however, serve a mimetic or imitational function (cf Kearney, op cit, 1988, 416 note 23).

17 Five main accusations is directed by Plato toward imagination: (1) ignorance (2) non-didacticism (3) immorality (4) irrationalism and (5) idolatry (cf Kearney, op cit, 1988, 98).

18 For a more elaborate expostion of the important difference between Plato and Aristotle, see Kearney, op cit, 1988, $106 \mathrm{ff}$ and Kearney, op cit, 1991, 3.

19 For the linking by Aristotle of imagination to desire, and its implicated relation to time, see Kearney, op cit, 1988, 110.

20 See Kearney, op cit, 1991, 3.

21 See Kearney, op cit, 1988, 115.

22 See Kearney, op cit, 1988, 116ff; cf Kearney, op cit, 1991, 3.

23 See Kearney, op cit, 1988, 128ff.

24 Kearney, op cit, 1988, 129 states in this regard: "This metaphor of the 'storehouse' is perhaps the paradigmatic figure of imagination in Thomistic philosophy and, one could even argue, in the mainstream of medieval scholasticism as a whole".

25 Kearney, op cit, 1988, 131 does not put it so bluntly, but speaks of the "ambigious status of imagination", of the "largely hostile view of imagination" and the "antipathy" to imagination of medieval philosophy.

26 See Kearney, op cit, 1988, 155; Kearney, op cit, 1991, 4.

27 Why a "Copernican Revolution"? Being was the centre of the universe and the human mind was like a planet which revolved around it. Kant reversed this model. Being would henceforth be conceived not as the transcendent origin of meaning, but as a representation of the human subject. 
28 Kearney, op cit, 1988, $158 \mathrm{ff}$ calls these forerunning roots "transitional movements".

29 See Kearney, op cit, 1988, 159.

30 This Cartesian hostility was shared by such rationalist philosophers of the seventeenth century as Leibniz and Spinoza.

31 Kearney, op cit, 1988, 162 remarks: "(W)hile Descartes was incontestably 'modern' in his positive evaluation of the cogito, he was essentially 'premodern' in his negative assessment of imagination".

32 For the difference between Kant and his "forerunners", see Kearney, op cit, $1988,168 f f$.

33 It is important to note that Kant situated this transcendental realm in the human mind and not - as in Platonic metaphysics - in some other-world of Eternal Forms (cf Kearney, op cit, 1988, 168).

34 Kearney, op cit, 1988, 157. For a detailed discussion of Kant's theory of imagination as well as for references to secondary literature, see Kearney, op cit, 1988, 154ff, $189 \mathrm{ff}$ and $425 \mathrm{ff})$.

35 With regard to the connection between Kant and German idealism - a neglected connection which Heidegger was the first to make - Kearney, op cit, 1988, 177 remarks: "Schelling and Fichte may be said to have inflated the power of transcendental imagination to such a point that the canonical distinctions of traditional epistemology dissolve".

36 Kearney, op cit, 1988, 185 writes: "Confronted with the increasingly disabling realities of modern existence - the crushed political revolutions, the industrial devastation of nature, the bureaucratization and mechanization of society promoted by market and monopoly capitalism - the humanist hopes of both the enlightenment and of romanticism were steadily eroded".

$37 \quad$ Kearney, op cit, 1988, 198.

38 See Kearney, op cit, 1988, 196.

39 The first and second generation are chronological references, i e, the 19 th and 20 th century respectively.

40 The Danish thinker Kierkegaard's (using the terms Phantasi or Indbildning) basic concern was to unravel the relationship between man's aesthetic (that is, the youthful passion for the possible) and religious experience. The aesthetic attitude, Kierkegaard insisted, was but the first stage on life's way, the other two being the "ethical" and the "religious". It is precisely the ethical and religious stages which set limits to the creative imagination. The ethical presented responsibilities, the religious the leap of faith, characterised by risk und uncertainty and made in fear and trembling. For Kierkegaard, no salvation was to be found either in the world or in the self (see Kearney, op 
cit, 1988, 201-211).

41 "Let nothingness be!" was not nihilism. For Nietzsche, nihilism is the covering up of nothingness by Christianity, morality and speculative philosophy. Nihilism was the negation of this life in favour of another one (cf Kearney, op cit, 1988:215).

42 For Nietzsche, Christianity was nothing but "Platonism" for the people. Nietzsche consequently reversed Kierkegaard's model of the three stages, hailing the aestetic stage as the highest expression of existence!

43 Kearney, op cit, 1988, 218 remarks: "The belief in the inevitable progress of history, or indeed of human consciousness, was no longer tenable after the holocaust and the barbaric consequences of modern totalitarianism".

44 To exemplify this "absurdity", Camus chose the myth of Sisyphus who was condemned by the gods to repeatedly push a rock up a mountain, knowing that on each occasion the rock would roll back again before he reached the top.

45 See Heidegger's Kant and the problem of Metaphysics, 1929.

46 See Kearney, op cit, 1988, 223-4.

47 Imagination (1936) and The Psychology of Imagination (1940) was Sartre's first two major works. In these two works, he gives a painstaking and comprehensive description of the existential act of imagining.

48 For the very specific understanding of the concept of nothingness by Sartre, see Kearney, op cit, 1988, 228ff; Kearney, op cit, 1991, $51 \mathrm{ff}$.

49 Kearney, op cit, 1991, 51.

50 As act of negation, imagination was at the same time an act of fascination. These were two sides of the same coin (cf Kearney, op cit, 1988, 229).

51 Kearney, op cit, 1988, 236 explains this difficult affirmation of Sartre as follows: "It is only because man is transcendentally free that he can imagine, and only because he can imagine that he is transcendentally free. It is the possibility of the unreal which provides us with the freedom to found the real".

52 The term "postmodern" was used as early as 1938 by the historian Arnold Toynbee. In 1971 Ihab Hassan, a literary critic, also made use of the term. It was however in architectural theories of the mid-seventies (e $\mathrm{g}$ by Jencks, Venturi, Moore, Graves, Portoghesi) that it first achieved international recognition as a critical term (cf Kearney, op cit, 1991, 202 note 2). Since then, it was especially used by literary critics of the late seventies and eighties (cf Kearney, op cit, 1991, 171). Many postmodern philosophers however such as Derrida, Lacan, Foucault, Baudrillard, Barthes - do not use this term. Others - such as Lyotard, Vattimo, Kristeva - do. 
53 See Kearney, op cit, 1988, 25 I and Kearney, op cit, 1991, 170.

$54 \quad$ Kearney, op cit, 1988, 251-2.

55 Kearney, op cit, 1988, 253; cf Kearney, op cit, 1991, 170-1.

56 With parody - in short - is meant that the role of the image no longer refers primarily to some original situated outside itself in the real world or inside human consciousness. Devoid of any fixed references to an origin, the image appears to refer only to other images, that is, the image circulates in a seemingly endless play of imitation.

57 Our contemporary culture has been greatly informed by the radical discovery of the unconscious. Psychoanalysis revealed the unconscious as a playground of images and symbols which defy the laws of formal logic. The logic of the imaginary is one of both/and (that is, inclusive and - by extension - tolerant) rather than either/or (cf Kearney, op cit, 1988, 368).

58 For short discussions of their work as well as that of Roland Barthes, see Kearney, op cit, 1988, 256-95; cf Kearney, op cit, 1991, 172-7.

59 Kearney, op cit, $1988,388$.

60 Kearney, op cit, 1988, 361.

61 Examples of postmodern philosophies in which contemporary imaginary take account of the other are to be found in the works of Julia Kristeva (melancholic imagination through a pre-linguistic semiotics), Gianni Vattimo (fragile imagination through an anti-foundationalist aesthetics), JeanFrancois Lyotard (narrative imagination through a narrative pragmatics). For a discussion thereof, see Kearney, op cit, 1991, 182-209.

62 Whether we like it or not, might it not just be that this is the very challenge that we face, namely an age in which ethics has primacy over epistemology and ontology?

63 How? The face - for example - of a terrorist (the image of ruthless power) and the face of one being terrorised (the image of powerlessness) is simply not the same.

64 Cf Kearney, op cit, 1991, 178 where he states more explicitly: "What it does mean is that the imaginary is now recognized as a process which relates to something or somebody other than itself".

65 Such a response will also make use of all available technologies to pursue its concern for the other. In this way, our imaginitive horizons can be enlarged. It can also allow for the possibility of a democratization of knowledge and culture (cf Kearney, op cit, 1988, 364-5.

66 Kearney, op cit, 1991, 210. 
67 Kearney, op cit, 1988, 368-9.

of There is of course many obstacles - the economic being the most daunting which must be tackled. See in this regard the discussion by Kearney, op cit, 1) $88,371$.

(6) Ce Kearney, op cit, 1988, 389-397.

70) This does not mean however, that the history of the life of Jesus of Nazareth is animportant. The very opposite is true. What we want to do with our historic reconstructions, that is the crux of the matter! 